\title{
Investigation of Discharge Measurements of the Lower Mississippi River below Natchez, MS
}

by James Lewis, Gary Brown, and Steven Ayres

MRG\&P Tech Note No. 3 • July 2017

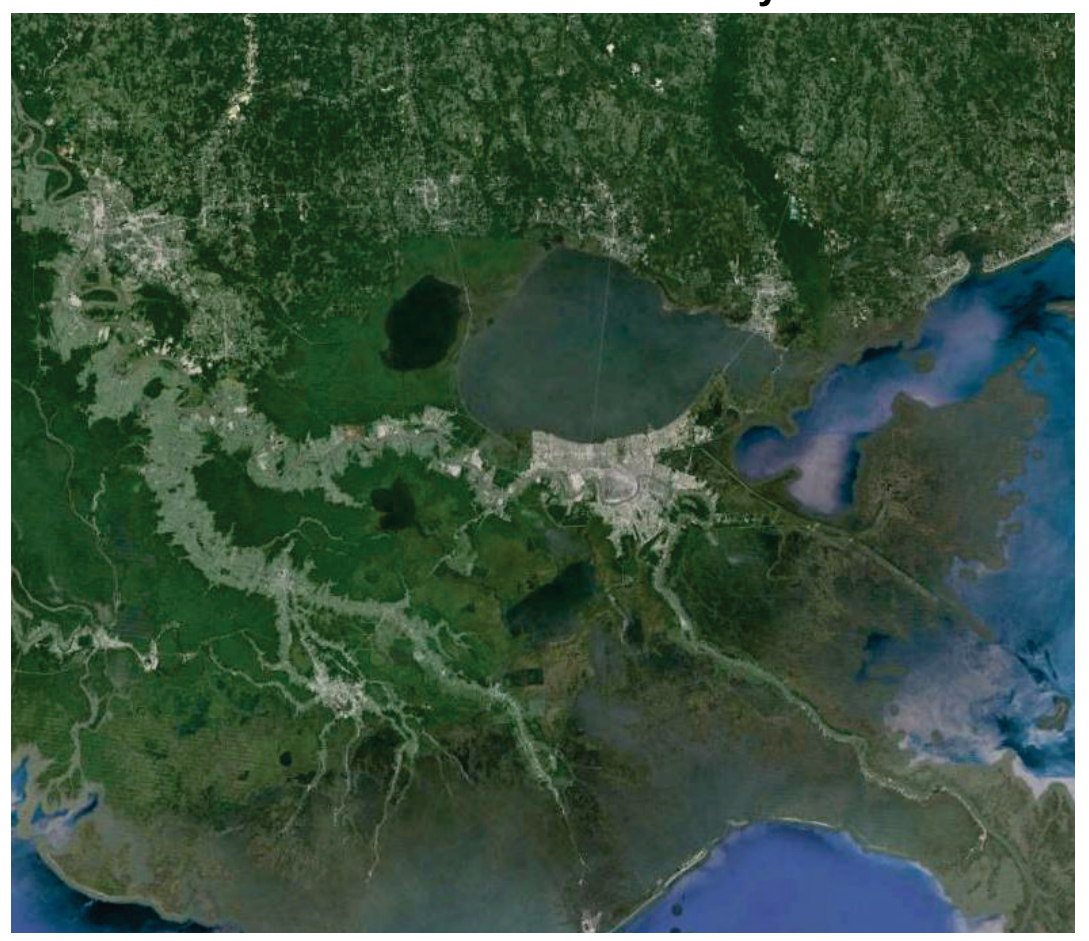

MRG\&P

Mississippi River

Geomorphology \&

Potamology Program

Approved for public release; distribution is unlimited. 


\section{MRG\&P \\ Mississippi River Geomorphology \& Potamology Program}

INTRODUCTION: A significant challenge during the 2011 Mississippi River flood was estimating the actual volumetric flow of water within the river. There were large disagreements among the various gages and measurements in May 2011. To address this issue (among others) (USACE 2012), the U.S. Army Corps of Engineers (USACE), Mississippi Valley Division (MVD), initiated the Mississippi River Geomorphology and Potamology Program (MRG\&P) in 2013, a revitalization of historic Mississippi River Potamology studies that were performed in the 1960s to 1980s (Biedenharn et al. 2014). The data collection and analysis within this study aim to improve the understanding of the water budget of the Lower Mississippi River through three primary objectives: to determine if there are systematic errors between gages in the Lower Mississippi River, to examine claims of a water volume loss between Baton Rouge and Belle Chasse, and to document extreme loss of flow from Natchez, MS, to the Head of Passes (HOP).

For most rivers, the flow increases in the downstream direction because of an increasing drainage area reaching each downstream location, although there are plenty of exceptions. In general, the Lower Mississippi River is one of those exceptions, where the flow within the river does not always increase in the downstream direction. In addition to the man-made diversion through the Old River Control Complex (ORCC), there is also a significant decline of the Mississippi River discharge between ORCC and HOP. The majority of this water loss occurs through the delta distributaries and Fort St. Philip leakages (Sharp et al. 2013). It is also known that the Bonnet Carre Spillway (BCS) continuously leaks several thousand cubic feet per second through the needle gates of the structure, when the river stage is high enough to inundate the gates. However, even when all of the known diversions of water are accounted for, the water budget for the Mississippi River still does not close. This has led to speculation about possible additional discharges from the river, potentially associated with groundwater losses.

Evidence of freshwater signals within coastal estuaries near the Mississippi River led Kolker et al. (2013) to hypothesize that a significant amount of water may be exiting the river through sandy underground paleochannels, connecting the river to adjacent bays. They demonstrated that the chemical signature of freshwater entering Barataria Bay is clearly evident. One of the primary means they used for estimating the volume of water associated with this signal was to associate the quantity of the groundwater flux with the residual of the Mississippi River water budget, computed by integrated existing observations of discharge in the river.

This study is designed to determine, by direct observation, if there is indeed an unexplained residual in the water budget that could potentially indicate some other significant source/sink to the river (such as groundwater flux). The methods and results are given below.

DATA COLLECTION: The inability to close the water budget associated with the historic discharge observations between Tarbert Landing and Belle Chasse (Allison et al. 2012; Kolker et al. 2013) triggered this investigation. Prior to field measurement collection, preliminary assessments of the recent discharge records to identify discrepancies included data sets at Natchez, Old River Control Complex, Tarbert Landing, Morganza Control Structure, Baton Rouge, Davis Pond, Caernarvon, BCS, and Belle Chasse. The locations of these gages can be seen in Figure 6. The Baton Rouge (U.S. Geological Survey [USGS] gage \# 07374000) computed discharge estimates are based on a stage vs. discharge rating curve. The discharge at Tarbert Landing (USACE RiverGages.com, 01100Q) is based on a rating curve using the stage at Red River 


\section{MRG\&P \\ Mississippi River Geomorphology \& Potamology Program}

Landing. The rating curves are periodically adjusted based on Acoustic Doppler Current Profiler (ADCP) measurements. The Natchez discharge measurements are available from USACE at http://www.rivergages.com through the Vicksburg District. ORCC discharge is from the sum of the computed flows through the three individual structures (from USACE RiverGages.com, Old River Outflow Channel - Total Discharge, 02600Q). A comparison was performed between this USACE ORCC data set and the USGS gage called Old River Outflow Channel below Hydropower Channel (USGS gage \# 07381482), and these two data sets were very similar. The USGS gage had a significant gap in discharge data for 2011, so the USACE data set was used for ORCC for this study. Morganza Control Structure and BCS estimated discharges were from the USACE New Orleans District. Belle Chasse (USGS gage \# 07374525), Davis Pond (USGS gage \# 295501090190400), and Caernarvon (USGS gage \# 295124089542100) are estimated using velocity measurements from Horizontal Acoustic Doppler Current Profilers (H-ADCP).

Discharge data for the years 2004, 2008, 2009, and 2011 indicated that the discharge discrepancies were particularly noticeable when the discharge was high (i.e., over approximately 800,000 cubic feet per second [cfs]), as seen in Figure 1 through Figure 4. In the figures, Caernarvon ("C"), Davis Pond ("DP"), Bonnet Carre Spillway ("BCS"), and Morganza Control Structure discharges were added to the downstream location(s) for a consistent comparison. None of the discharge data sets stand out with a consistent bias through all four figures. Sometimes the Natchez minus ORCC and Baton Rouge estimates agree well (such as April 2008), but at other times the Natchez minus ORCC estimates agree well with Tarbert Landing and not as well with Baton Rouge (such as December 2004). Figure 5 shows a plot zoomed to the 2008 flood peak comparing the computed rating curves of Tarbert Landing and Baton Rouge with observed discharge measurements. In these figures, the data labeled "computed" indicate that a rating curve was used to compute discharges from stages, and "observed" indicates actual discharge measurements. Tarbert Landing measurements are from the New Orleans District, and Baton Rouge measurements are from USGS's website. The plot exhibits a large scatter for the Tarbert Landing location, similar to 2011 (O’Brien et al. 2012).

Using this information, and with funding from the MRG\&P Program, the USACE New Orleans District (MVN) conducted ADCP measurements at 31 locations along the Lower Mississippi River in the spring of 2014 when the flow passing the Natchez, MS, gage was over 1,000,000 cfs. The ADCP measurements were conducted in a downstream order, or Lagrangian fashion (i.e., the rate of observation was timed to follow a specific "water mass" as it moved downstream). The ADCP equipment used in this investigation was a SonTek M9, and a Trimble GPS (Differential) was used for positioning. The 2014 measurements occurred over the course of 5 days, April 21-25. Four passes were generally performed for each location, with each pass providing a discharge estimate. In other words, the boat conducting the ADCP measurements traversed back-and-forth and then again back-and-forth. The MVN survey crew follows USGS standards for ADCP measurements (Mueller et al. 2013). These four passes were used in the calculation of the average volumetric flow and standard deviation of the flow. Figure 6 shows the map of ADCP measurement locations. 


\section{MRG\&P \\ Mississippi River Geomorphology \& Potamology Program}

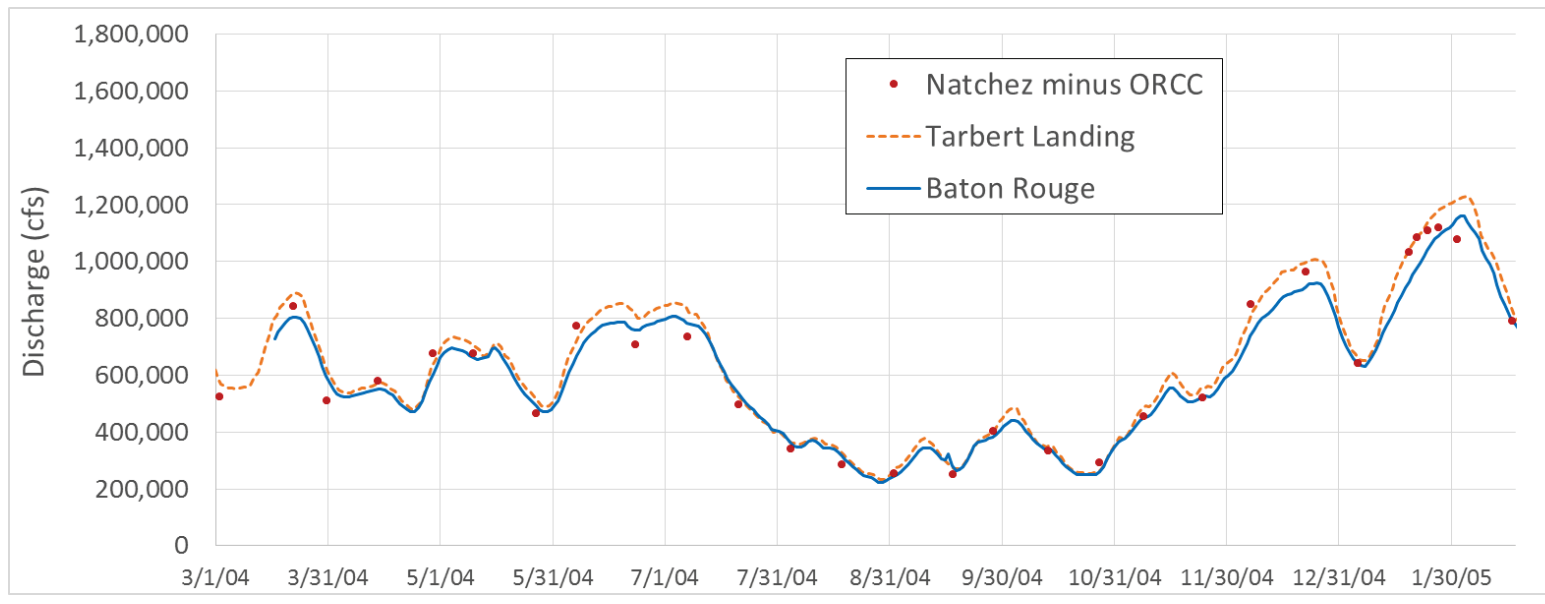

Figure 1. Flow hydrographs comparing discharge estimates from 2004.

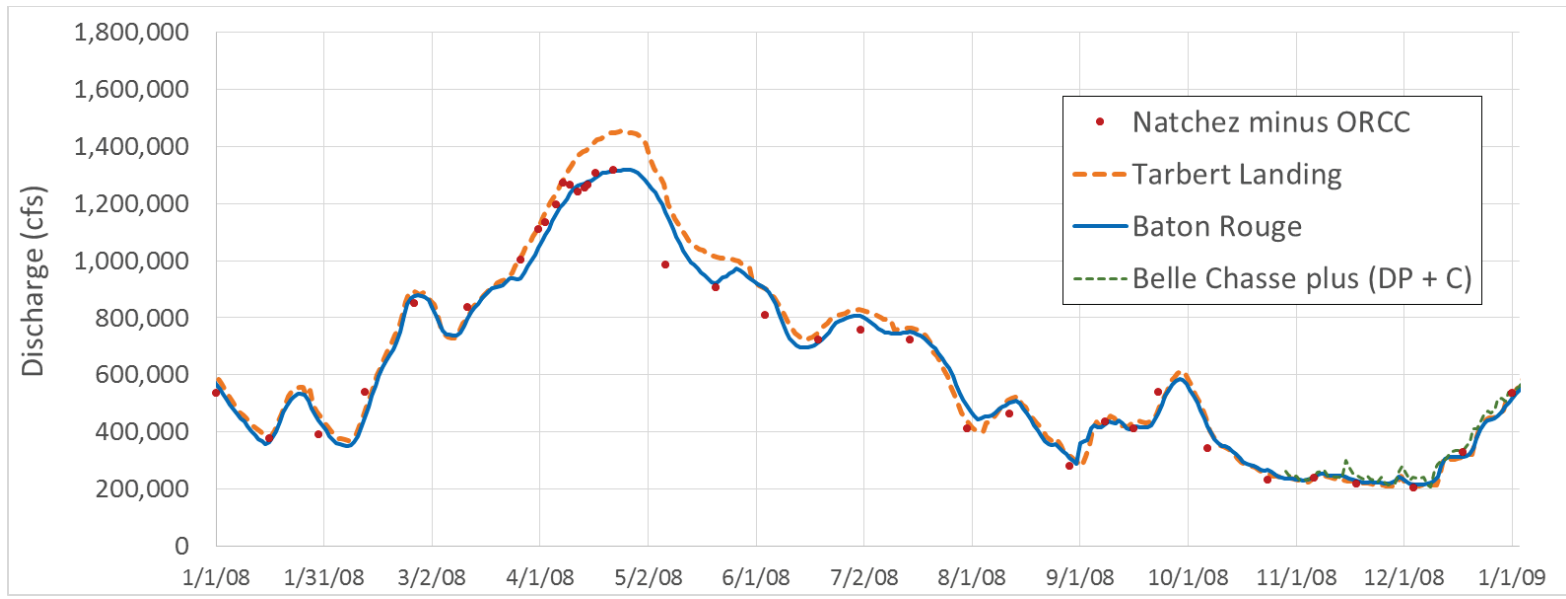

Figure 2. Flow hydrographs comparing discharge estimates from 2008.

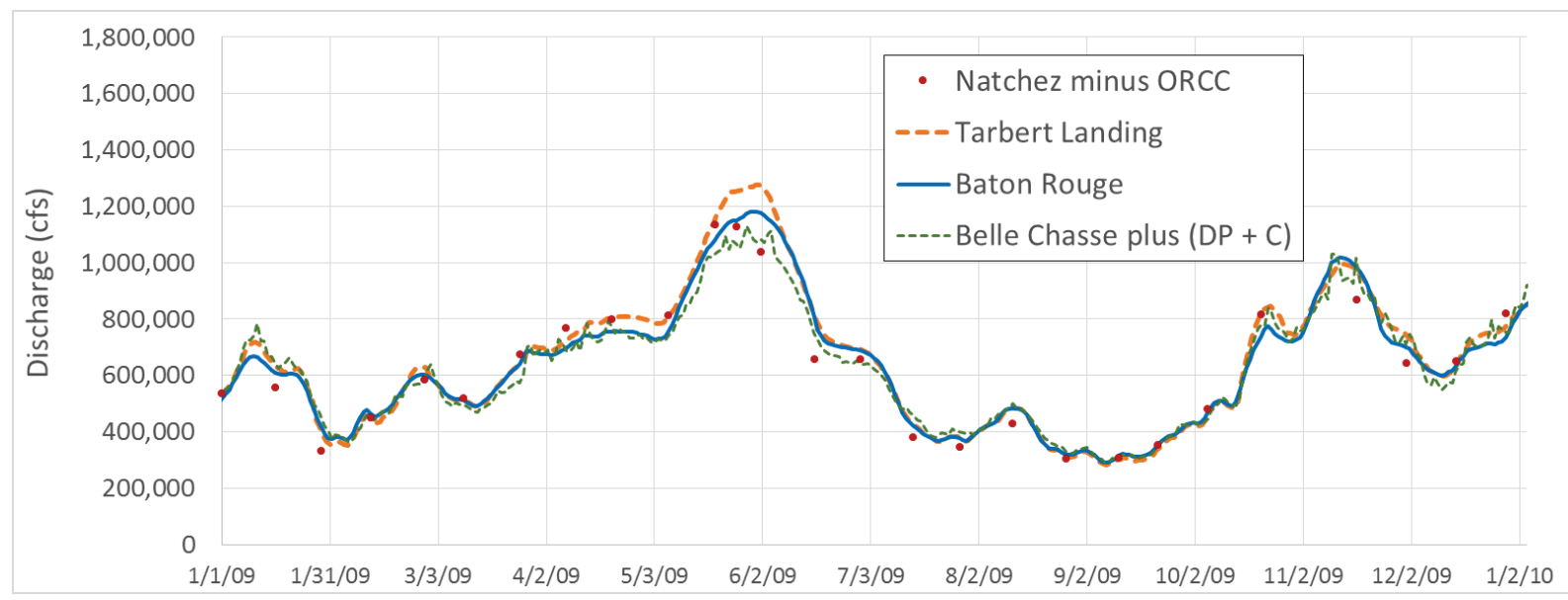

Figure 3. Flow hydrographs comparing discharge estimates from 2009. 


\section{MRG\&P \\ Mississippi River Geomorphology \& Potamology Program}

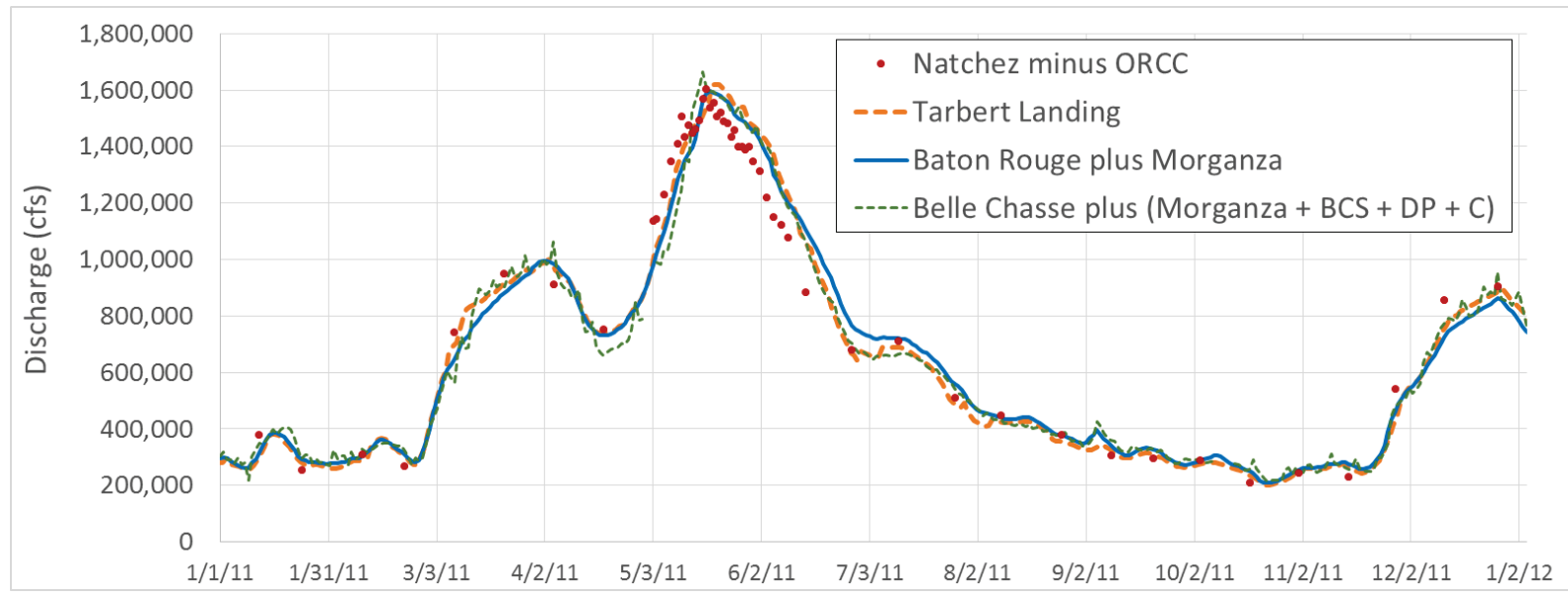

Figure 4. Flow hydrographs comparing discharge estimates from 2011.

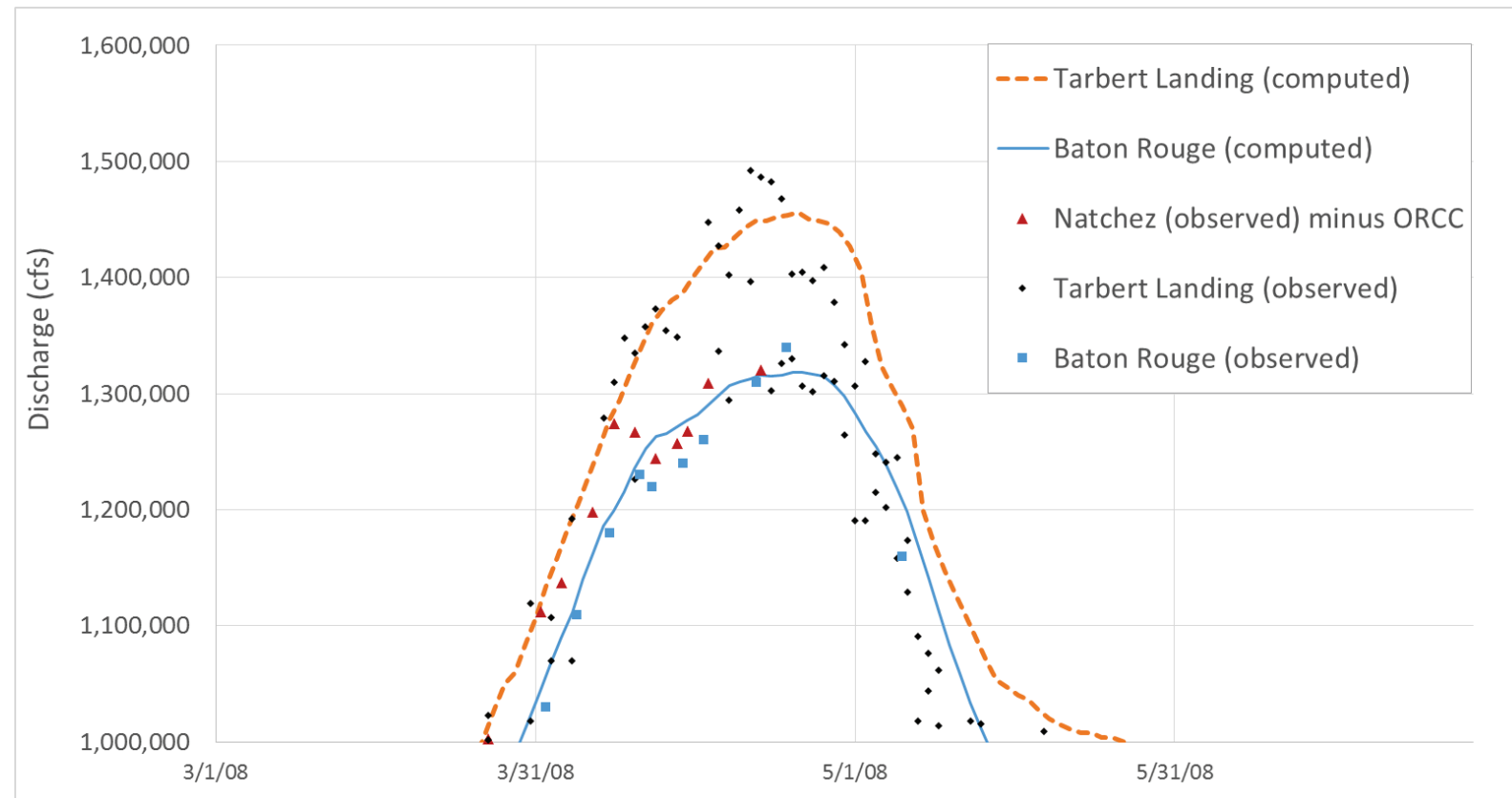

Figure 5. Computed and observed discharges during the peak of 2008. 


\section{MRG\&P}

\section{Mississippi River Geomorphology \& Potamology Program}

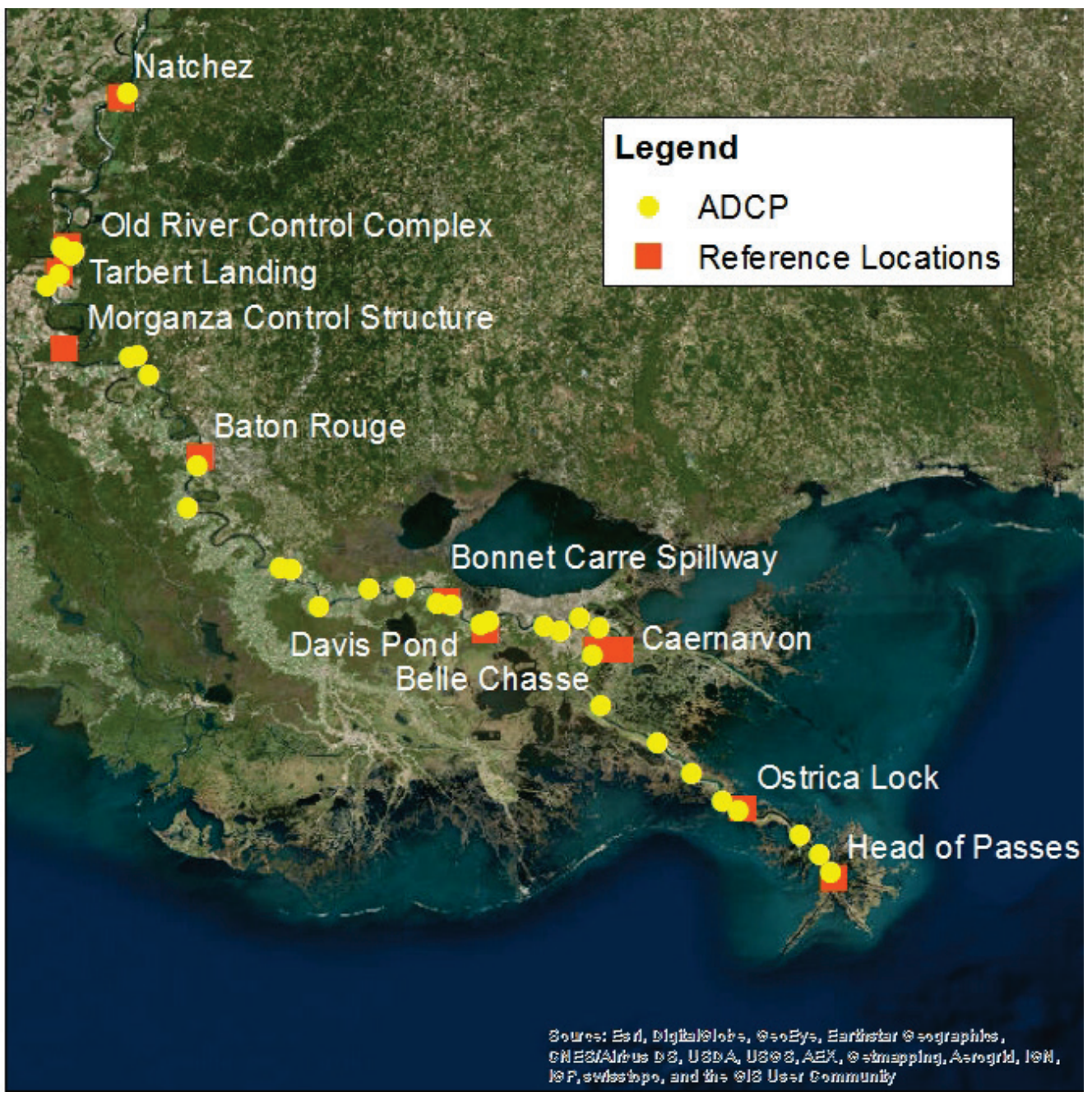

Figure 6. Map of measurement locations along the Lower Mississippi River.

For further discharge information during separate events, the same type of measurements were conducted again in the spring of 2015 and in January of 2016 at the same locations as shown in Figure 6. The 2015 measurements occurred over the course of four days, March 29 - April 1. The 2016 measurements occurred over the course of 11 days, January $16-26$. The equipment used for these measurements was the same as the 2014 measurements. Two passes were generally performed for each location in the 2015 and 2016 ADCP measurements. During the 2015 and 2016 measurements, the compass was calibrated at each measurement location. This recommendation for compass recalibration at each location came from communication with the Field Data Collection and Analysis Branch of the USACE Coastal and Hydraulics Laboratory in late 2014 while evaluating the 2014 data.

Similar to Figure 1 through Figure 4, the recorded flows at reference locations surrounding the timing of the 2014, 2015, and 2016 measurements are shown in Figure 7 and Figure 8. The purple circles in the figures indicate the timing of the ADCP measurements used in this study. Also, similar to Figure 5, the computed rating curves and observed discharges are compared in Figure 9. 


\section{MRG\&P \\ Mississippi River Geomorphology \& Potamology Program}

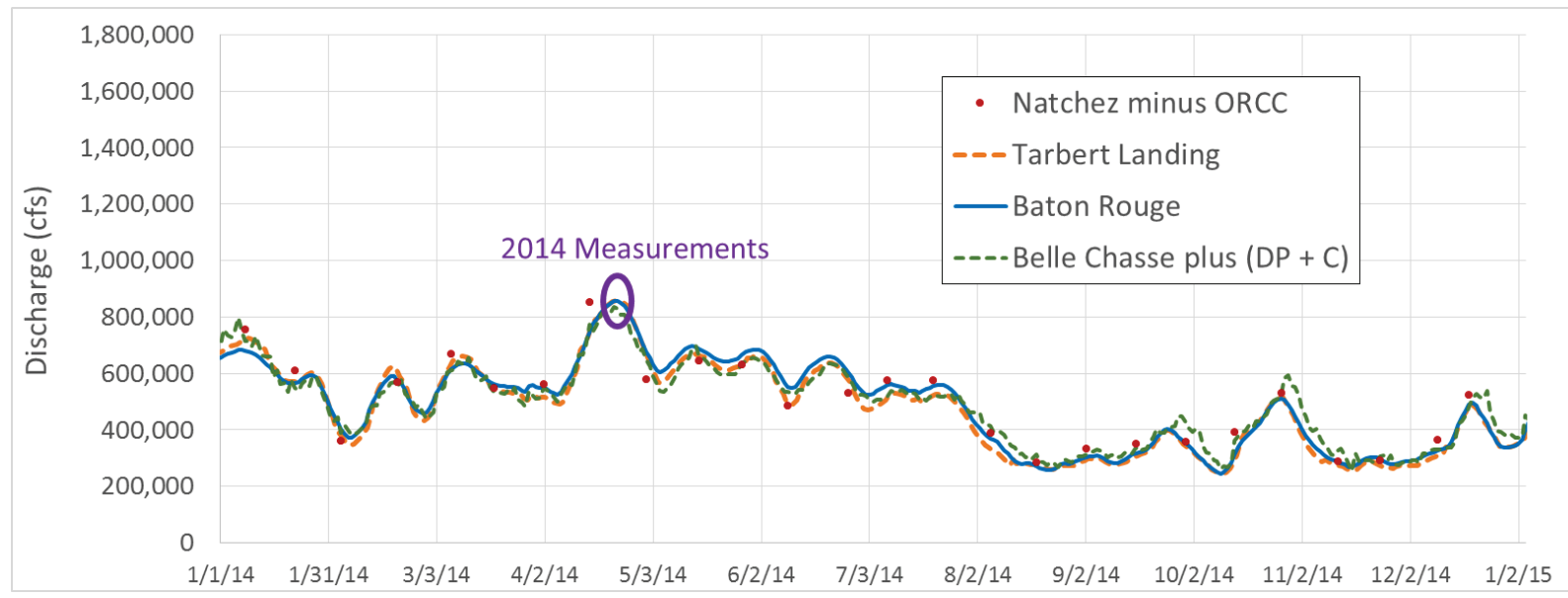

Figure 7. Flow hydrographs comparing discharge estimates from 2014.

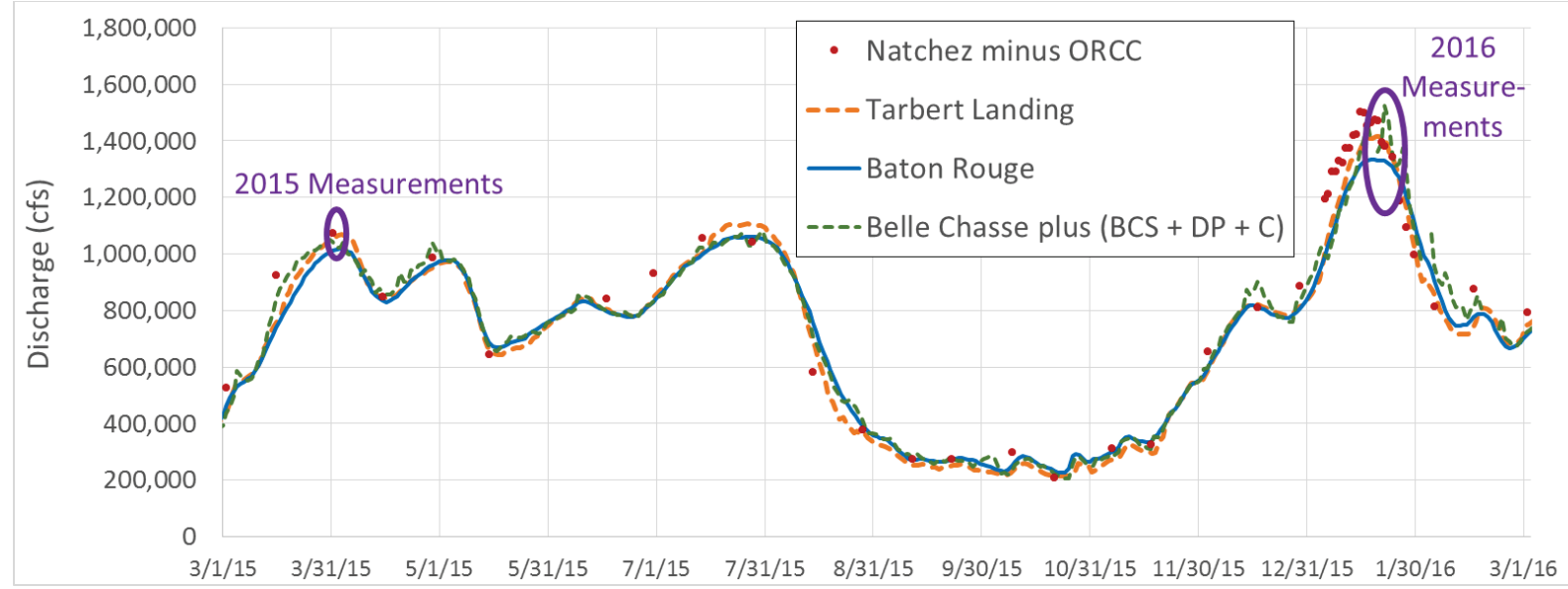

Figure 8. Flow hydrographs surrounding the 2015 and 2016 measurements. 


\section{MRG\&P \\ Mississippi River Geomorphology \& Potamology Program}

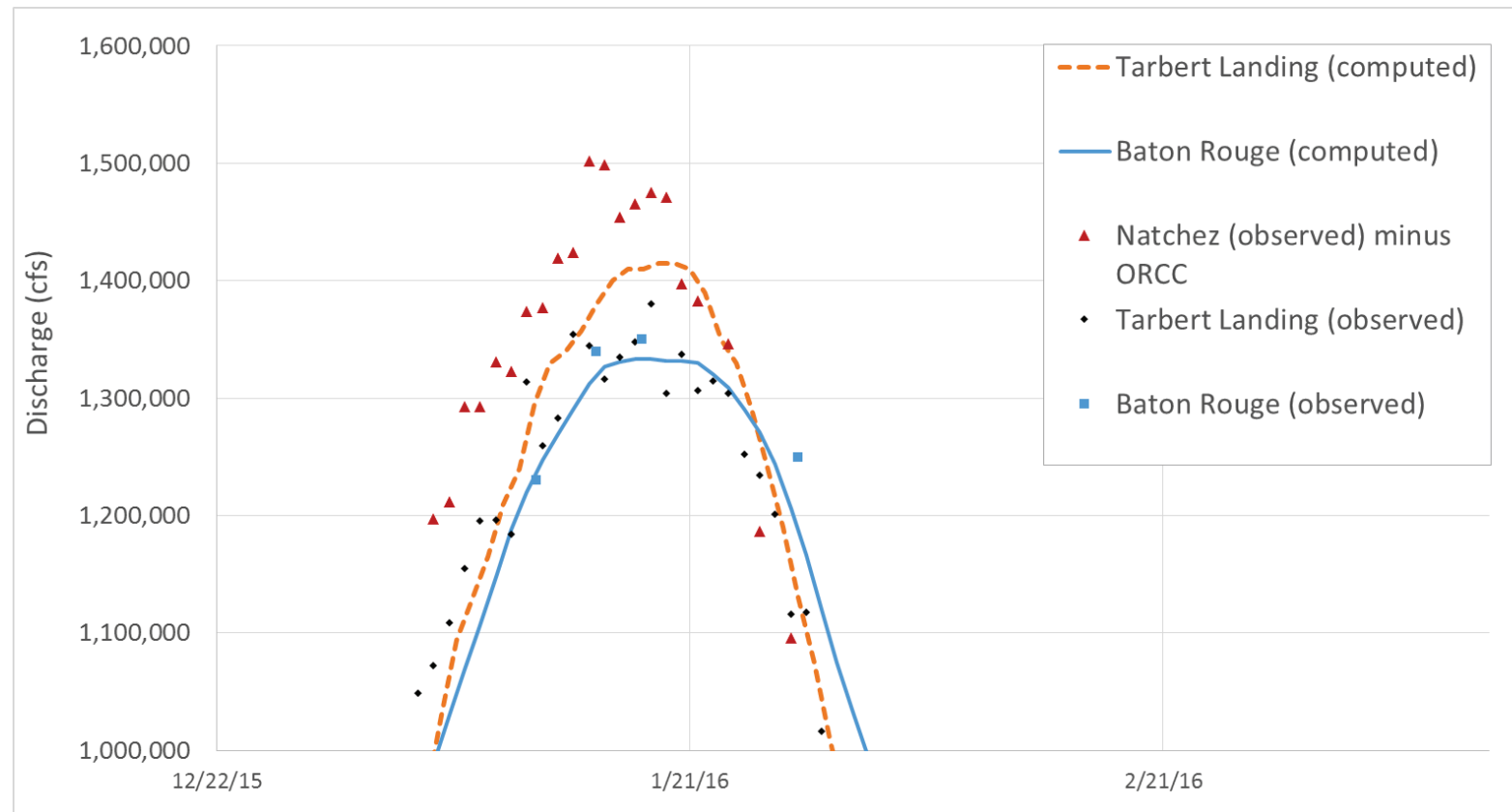

Figure 9. Computed and observed discharges during the peak of the 2016 winter.

RESULTS: Figure 10 shows the 2014 measured discharges, where the horizontal axis is the Mississippi River Mile location above HOP (River Mile 0). The farthest upstream extent of these measurements was Natchez, MS, at River Mile 363.52. Figure 11 shows the same data as Figure 10 but with a refined vertical scale between 700,000 cfs and 900,000 cfs. The error bars represent one standard deviation higher and lower, calculated from the four 2014 discharge measurements at each site. In each of the figures, Figure 10 and Figure 11, symbols also show the reported discharges of permanent gages at the time when the ADCP measurements were taken at that location.

The fluctuations observed in Figure 11 prompted a closer evaluation of the factors that may be impacting the measured river flow. The discharge data can also be viewed as a time series, with the horizontal axis showing the date and time of the measurements. Figure 12 shows the 2014 measurements in gray relative to the time-series data of reported discharge at the USGS Baton Rouge (blue) and Belle Chasse (red) gages. Since the field crew started upstream, the left-most gray line in the figure corresponds with the Natchez location. The corresponding gray lines represent the downstream progression through each of the locations shown in the map of Figure 6.

The Baton Rouge data is very smooth while the Belle Chasse data exhibits a wider range of fluctuations. This is partially due to the river conditions simply being more stable at the Baton Rouge location, but there are also two other reasons for different behavior at these gagesnamely the type of equipment and the tidal influence. The USGS Baton Rouge gage measures the stage of the river and uses a rating curve to compute discharge whereas the USGS Belle Chasse gage measures velocity and stage within the river to estimate the discharge. Additionally, evaluation of Figure 12 indicated that tidal influence was noticeable at the Belle Chasse gage, which is more clearly demonstrated in the stage data shown in Figure 13. Both of these factors contribute to wider variability in the Belle Chasse gage data compared to Baton Rouge. 


\section{MRG\&P}

Mississippi River Geomorphology \& Potamology Program

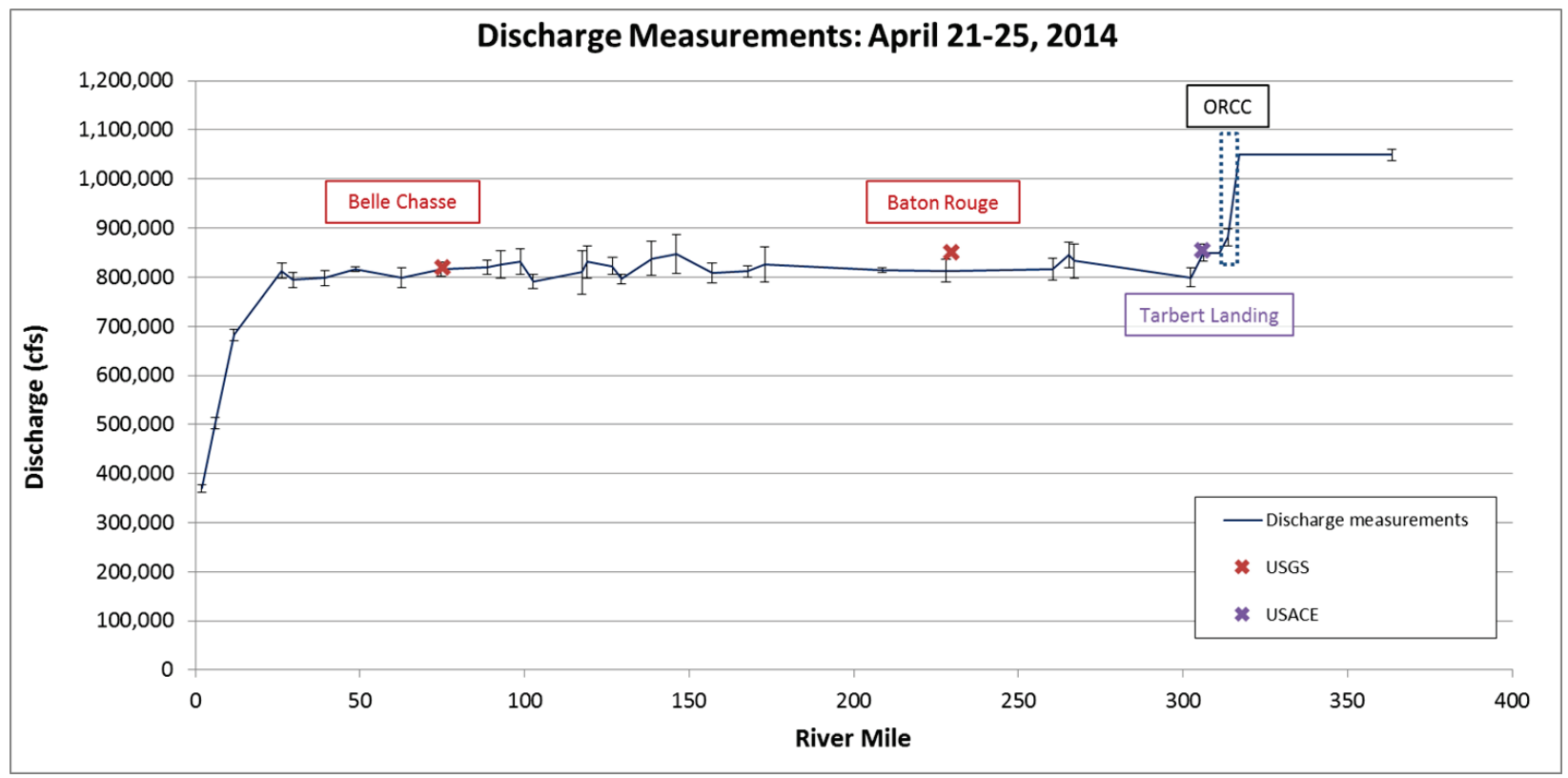

Figure 10. Discharge measurements of 2014.

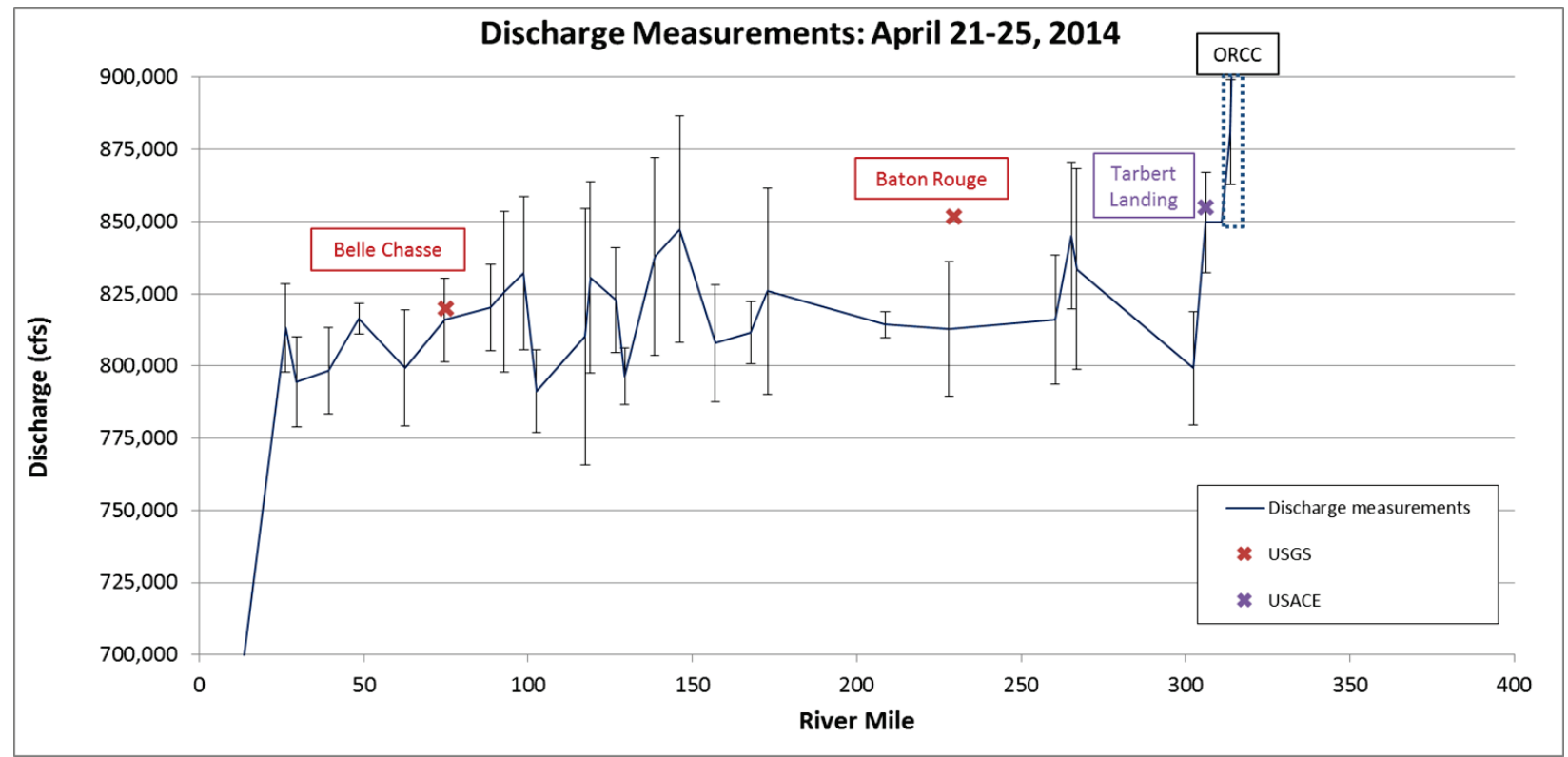

Figure 11. Zoomed-in view of 2014 discharge measurements. 


\section{MRG\&P}

\section{Mississippi River Geomorphology \& Potamology Program}

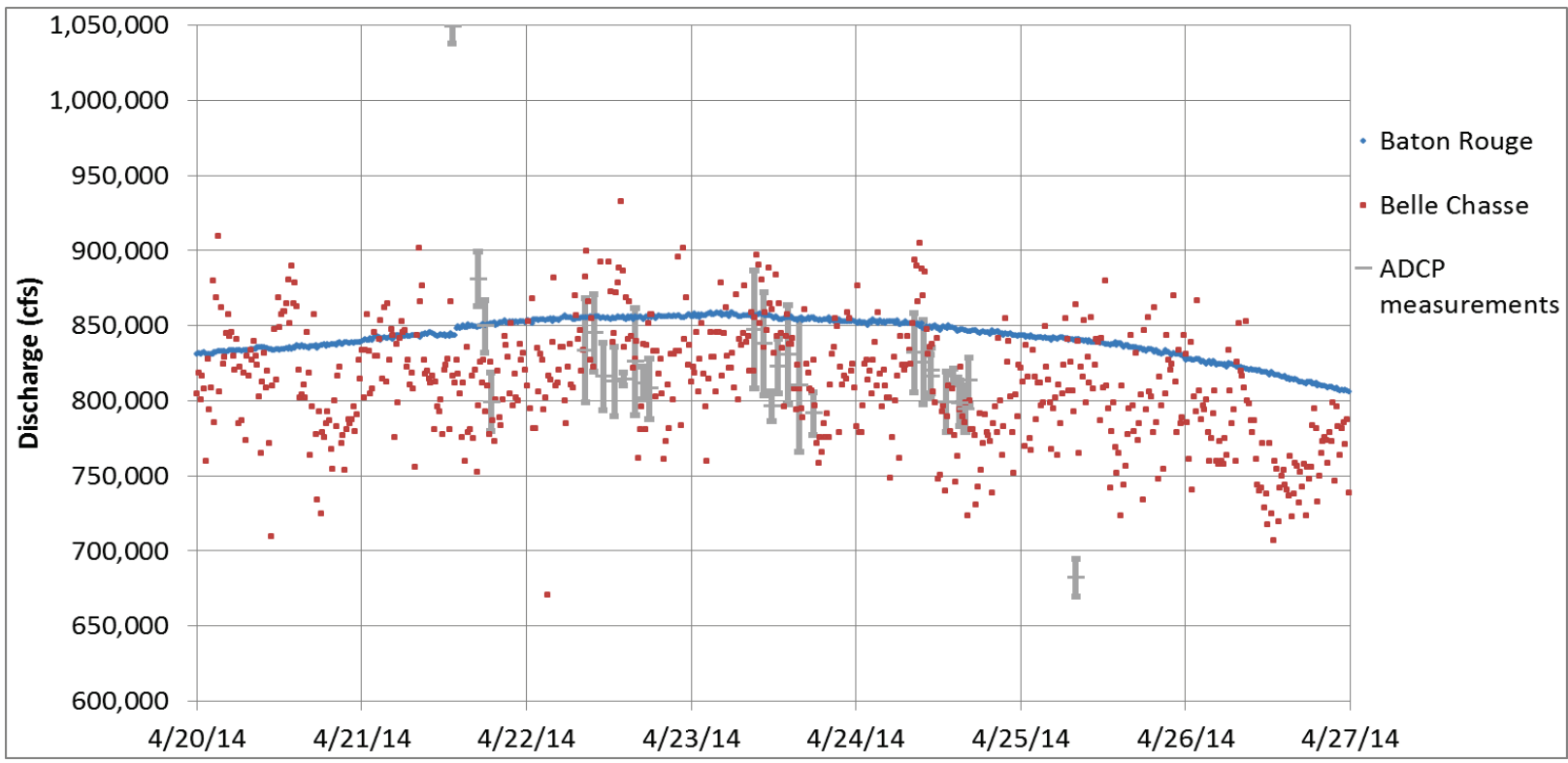

Figure 12. Time-series plot of 2014 measurements in comparison to USGS gages.

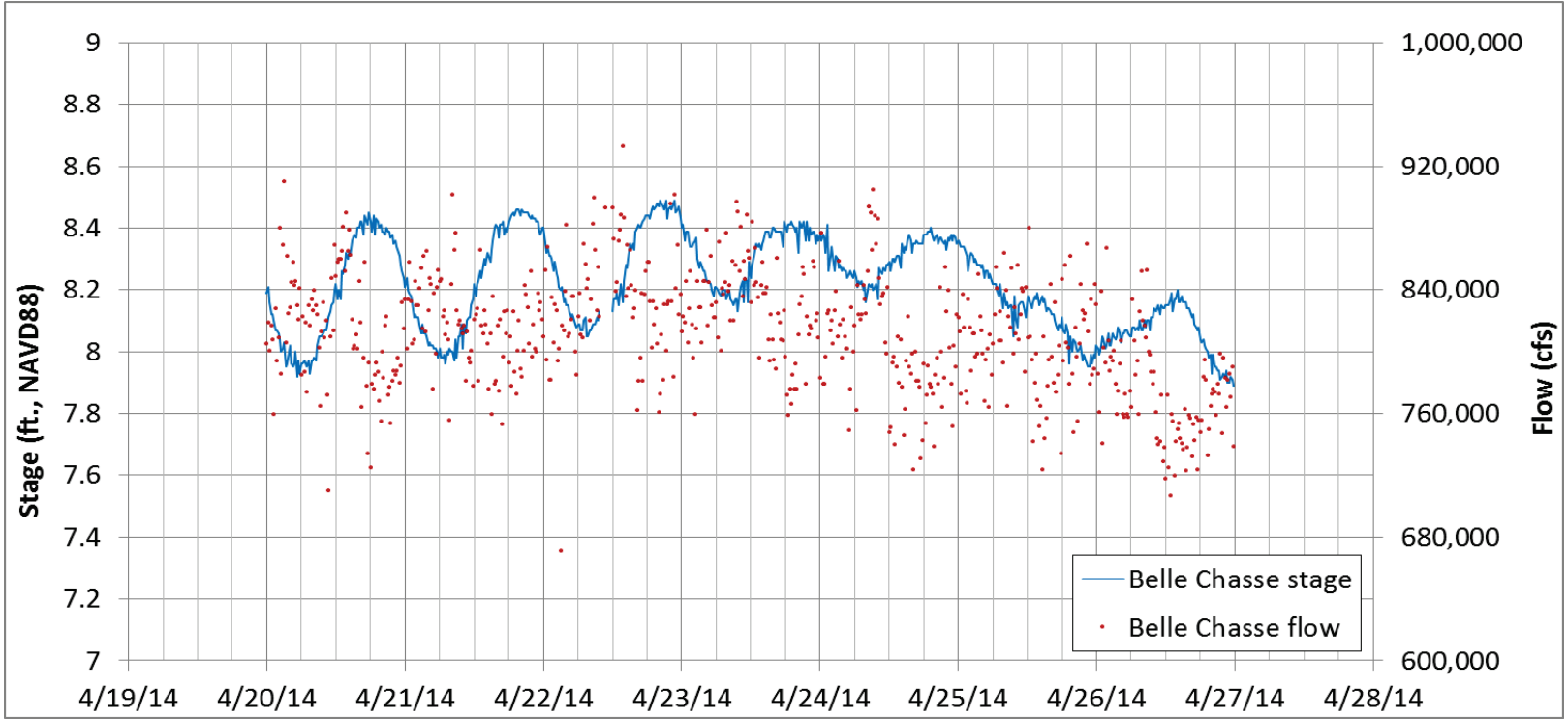

Figure 13. Time-series plot of Belle Chasse stage data showing tidal influence.

Tidal Correction. The tidal fluctuation causes the water flow in the lowest part of the river to increase and decrease due to the progression of the tide. As the downstream stage increases with a rising tide, the flow within the river decreases, and vice versa. Since one of the objectives of this investigation was to evaluate the water mass balance along the river, it is important to implement a tidal correction to have a consistent basis for comparing discharges at different measurement locations. The primary locations of interest for checking the water balance through the Lower Mississippi River are between Baton Rouge and Belle Chasse. The tidal correction is necessary for a consistent comparison of the discharges through this reach. 


\section{MRG\&P \\ Mississippi River Geomorphology \& Potamology Program}

The first step to perform the tidal correction was to evaluate the tidal behavior at the Belle Chasse gage location. The tidal behavior was evaluated by studying both the stage and flow data at Belle Chasse. A conversion factor was determined between stage and flow data by observing the tidal behavior of each. During the time of the 2014 measurements, a stage fluctuation of 0.4 foot (ft) caused approximately a 75,000 cfs fluctuation in flow, resulting in a conversion factor of 187,500 $\mathrm{cfs} / \mathrm{ft}$. A second-order polynomial was fit through the stage data to represent the non-tidal behavior of the water level at Belle Chasse. Then, in order to smooth out any instantaneous fluctuations in stage data, a 1-hour centered average was calculated from the 15-minute data. The difference between the second-order polynomial and the 1-hour average was considered to be the tidal influence in the stage. Using the conversion factor of $187,500 \mathrm{cfs} / \mathrm{ft}$, the tidal influence on the flow at Belle Chasse was determined for times during the measurement window.

Stage data were evaluated at other longer-term gage locations, including the Reserve (River Mile 138.7) and the Donaldsonville (River Mile 173.6) gages shown in Figure 14, finding evidence of the propagation of the tidal influence upstream with decreasing magnitude. The tidal behavior was not detectable in the Baton Rouge stage data, so the tidal influence was assumed to be zero at Baton Rouge. A linear interpolation was used between the tidal correction determined at Belle Chasse and zero tidal correction applied at Baton Rouge, based on the River Mile distance from Belle Chasse.

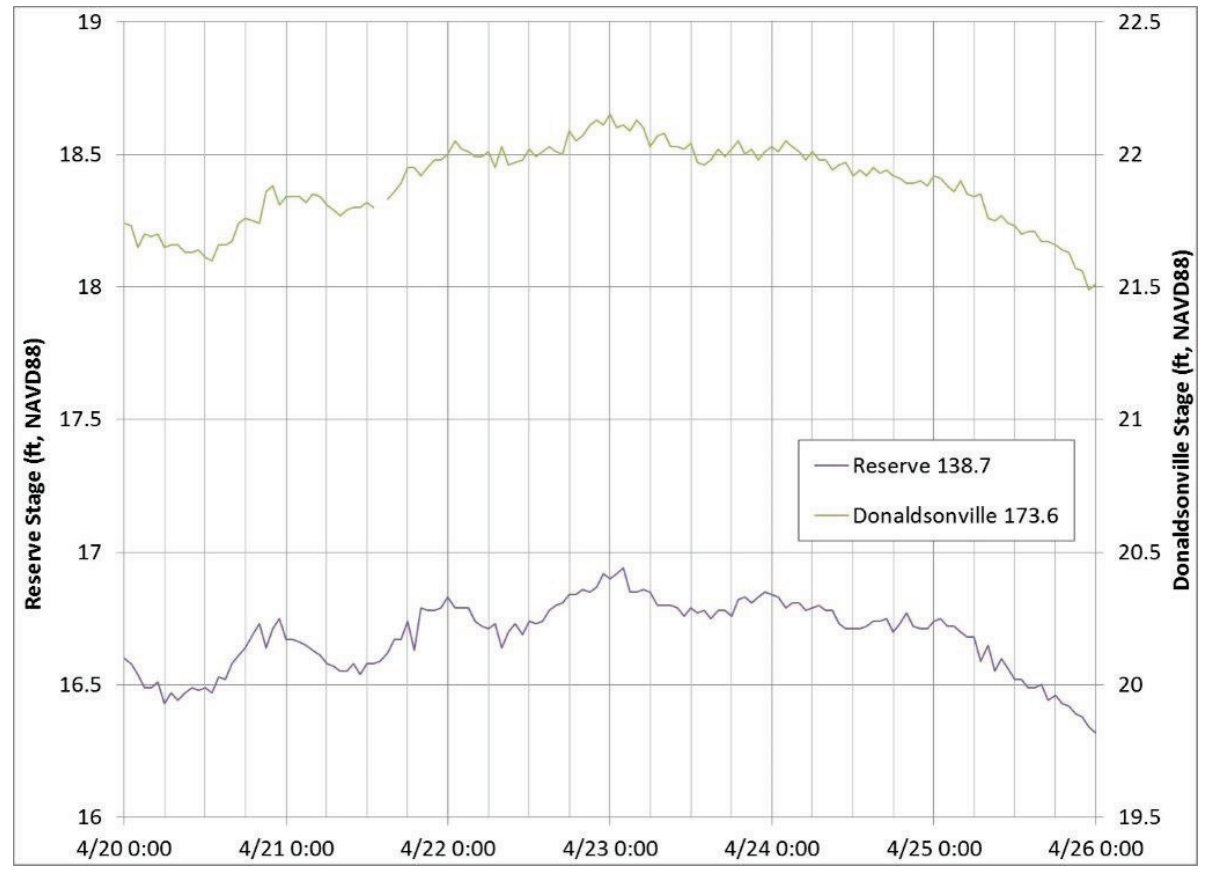

Figure 14. Tidal signal at other gages farther upstream.

The last factor in the tidal correction was considering the propagation time of the tidal influence. Stage data from Belle Chasse and Reserve showed approximately a 4-hour offset of the tidal behavior when matching peaks and valleys. Considering the distance between those two locations (64 River Miles), a propagation speed of approximately 16 miles/hour in the upstream direction was used when applying the tidal correction to the discharge measurements. In reality, the 
propagation speed varies based on localized water velocities and depths, but this approximation of 16 miles/hour was made for the overall reach. Figure 15 shows the tidal correction applied to the 2014 data.

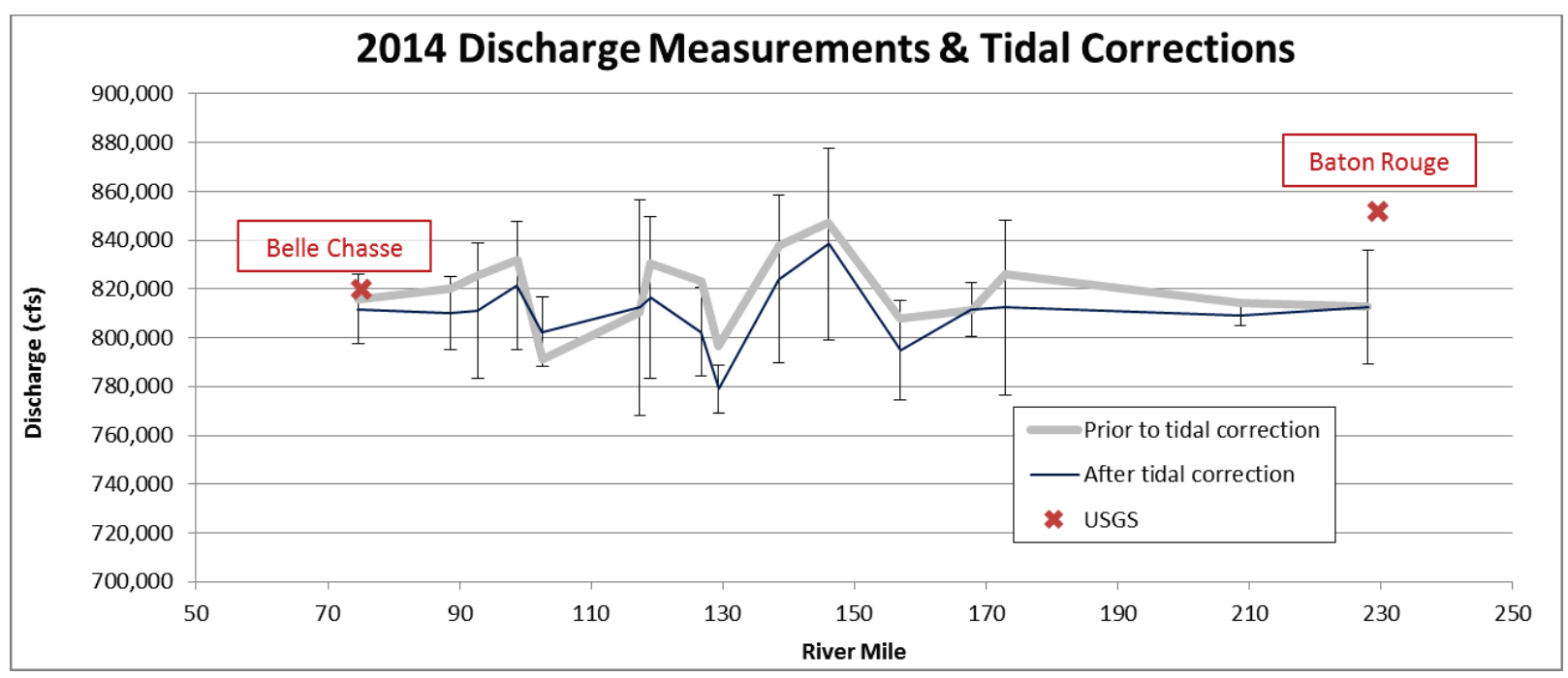

Figure 15. Tidal correction applied to the 2014 ADCP measurements.

The tidal correction adjusted many of the 2014 measurements into the range between 800,000 and $820,000 \mathrm{cfs}$, especially the seven measurements nearest to Belle Chasse. The tidal correction caused the measurement near River Mile 129 to become somewhat of an outlier as the lowest discharge between Belle Chasse and Baton Rouge. Interestingly, this same River Mile 129 measurement site in 2015 also recorded a low discharge, suggesting that perhaps the ADCP equipment may have a tendency to under-report the discharge at this specific location. The maximum depth of water at this location was $141 \mathrm{ft}$; this large of a depth could be a significant factor in measurement accuracy. With the exception of River Mile 129, the discharge consistency shown in Figure 15 indicates that there is no discernable trend of unaccountable water loss in the discharge observations for all cross sections between Baton Rouge and Belle Chasse. Any net gain or loss that exists between these ranges is well within the range of the uncertainty of the measurement at each cross section and hence undetectable in the observations. This consistency is in contrast with the apparent loss of water between the reported USGS observations for the Baton Rouge and Belle Chasse discharge ranges. The most likely explanation for this apparent loss, therefore, is observational error at one or both of the USGS observation ranges at Baton Rouge and Belle Chasse.

Figure 16 shows the 2014, 2015, and 2016 ADCP measurements with a similar tidal correction procedure being applied to each set. As seen in Figure 10, Figure 11, and Figure 16, there is a decrease in discharge upstream of Tarbert Landing due to flow diverted through the ORCC. Also, toward the downstream end of the Mississippi River, the flow is drastically reduced well before the river reaches the HOP. Table 1 shows how the discharge measurements decrease moving downstream. The fraction of flow remaining in the river, relative to the flow at Natchez, is relatively consistent from the 2014 measurements to those of 2015. In all 3 years, the main stem of the Mississippi River loses over $60 \%$ of its flow between Natchez and River Mile 1.88. This 


\section{MRG\&P \\ Mississippi River Geomorphology \& Potamology Program}

significant loss of flow in the Lower Mississippi River is a critical component of understanding the ecology and sediment transport capabilities of the lowermost Mississippi River. As noted by Allison et al. (2012), the significant diversion of river discharge upstream of the HOP into adjacent wetlands and shallow estuaries limits the amount of suspended sediment that is transported offshore to the continental shelf to a quantity much less than previously thought.

The 2016 measurements behave differently than the 2014 and 2015 measurements due to the operation of the BCS. The BCS is a flood control feature near River Mile 128 that is used to keep the volume of the Mississippi River flows at New Orleans from exceeding 1,250,000 cfs. It was not operated during the 2014 and 2015 measurements. The BCS began releasing flow on 10 January 2016, peaked on 17 January 2016 at approximately 203,000 cfs, and closed on 1 February 2016. The daily changes in operation of the BCS during the time of the ADCP measurements could potentially account for some of the additional fluctuations in discharge associated with the 2016 data in Figure 16.

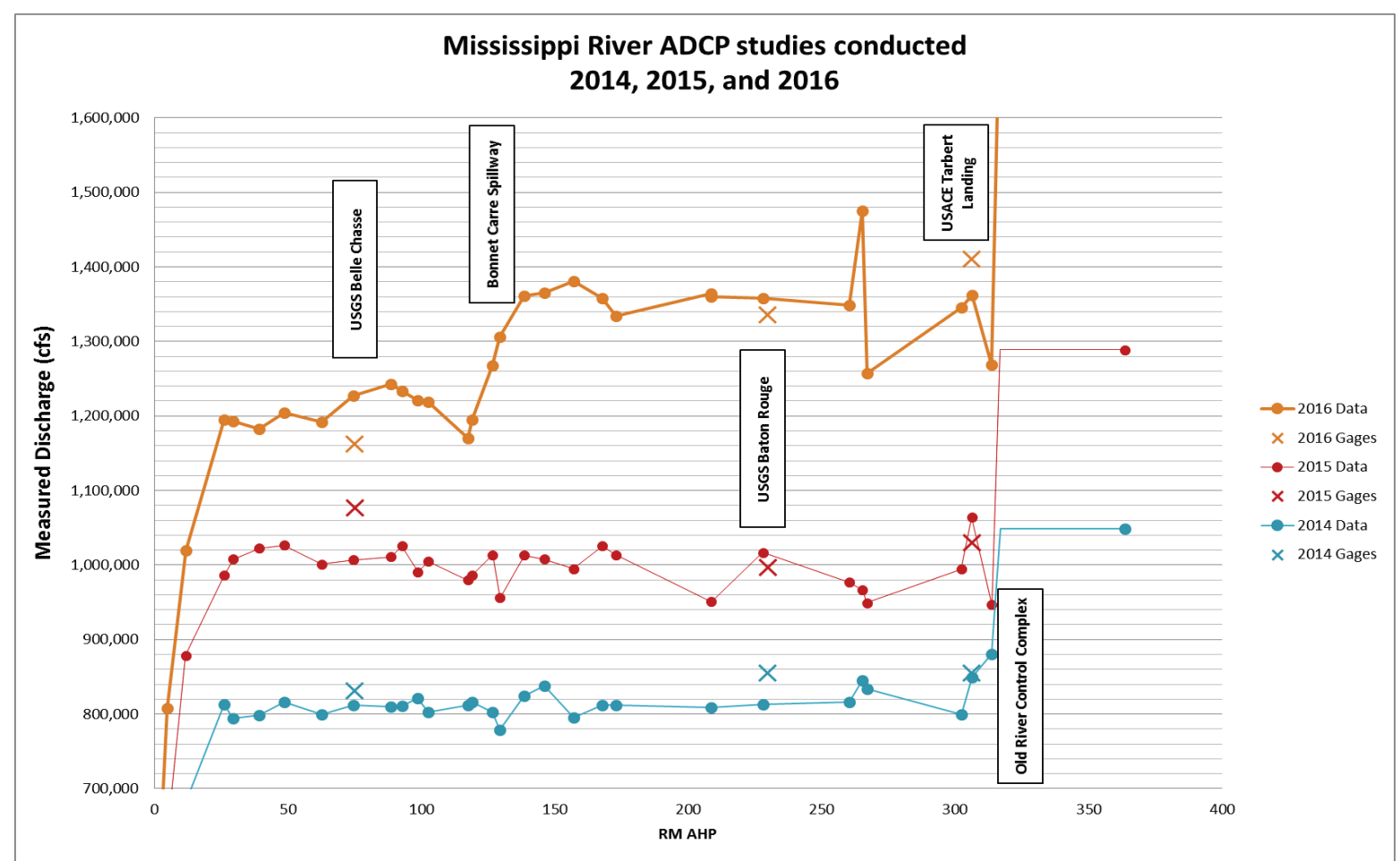

Figure 16. 2014, 2015, and 2016 ADCP measurements. 


\section{MRG\&P}

Mississippi River Geomorphology \& Potamology Program

\begin{tabular}{|c|c|c|c|c|c|c|c|}
\hline \multirow[b]{2}{*}{ Location } & \multirow[b]{2}{*}{$\begin{array}{l}\text { River } \\
\text { Mile }\end{array}$} & \multicolumn{2}{|c|}{2014 Measurements } & \multicolumn{2}{|c|}{2015 Measurements } & \multicolumn{2}{|c|}{2016 Measurements } \\
\hline & & $\begin{array}{l}\text { Avg. Flow } \\
\text { (cfs) }\end{array}$ & $\begin{array}{c}\% \text { of } \\
\text { Natchez }\end{array}$ & $\begin{array}{l}\text { Avg. Flow } \\
\text { (cfs) }\end{array}$ & $\begin{array}{c}\% \text { of } \\
\text { Natchez }\end{array}$ & $\begin{array}{l}\text { Avg. Flow } \\
\text { (cfs) }\end{array}$ & $\begin{array}{c}\% \text { of } \\
\text { Natchez }\end{array}$ \\
\hline Natchez & 363.52 & $1,048,912$ & 100 & $1,288,463$ & 100 & $1,795,112$ & 100 \\
\hline $\begin{array}{l}\text { [outflow] Old River } \\
\text { Control Complex }\end{array}$ & $\begin{array}{c}312- \\
316\end{array}$ & 228,000 & 22 & 270,000 & 21 & 376,000 & 21 \\
\hline Tarbert Landing & 306.24 & 849,666 & 81 & $1,064,035$ & 83 & $1,362,479$ & 76 \\
\hline Baton Rouge & 228.06 & 812,800 & 77 & $1,016,966$ & 79 & $1,358,232$ & 76 \\
\hline $\begin{array}{l}\text { [outflow] Bonnet } \\
\text { Carre Spillway }\end{array}$ & 128 & 0 & 0 & 0 & 0 & $\begin{array}{c}\text { up to } \\
203,000\end{array}$ & 11 \\
\hline $\begin{array}{l}\text { [outflow] } \\
\text { Davis Pond }\end{array}$ & 118 & 605 & 0.06 & 983 & 0.08 & 1180 & 0.07 \\
\hline $\begin{array}{l}\text { [outflow] } \\
\text { Caernarvon }\end{array}$ & 81 & 144 & 0.01 & 768 & 0.06 & 189 & 0.01 \\
\hline Belle Chasse & 74.61 & 815,985 & 78 & 993,019 & 77 & $1,227,074$ & 68 \\
\hline $\begin{array}{c}\text { Above Ostrica } \\
\text { Lock }\end{array}$ & 26.24 & 813,147 & 78 & 986,637 & 77 & $1,195,215$ & 67 \\
\hline $\begin{array}{l}\text { Above Venice } \\
\text { Jump }\end{array}$ & 11.72 & 682,075 & 65 & 878,587 & 68 & $1,019,102$ & 57 \\
\hline Above Westbay & 6.05 & 502,385 & 48 & 684,384 & 53 & 808,264 & 45 \\
\hline Above HOP & 1.88 & 369,527 & 35 & 508,924 & 39 & 589,687 & 33 \\
\hline
\end{tabular}

Uncertainties were also evaluated from year to year to search for patterns within specific measurement locations. For example, the authors investigated whether measurements made at sites within bends of the river consistently portrayed greater uncertainty. This analysis of the data, along with discussions among ADCP field measurement experts, was inconclusive in determining consistent uncertainties at any particular sites, but the discussions led to several valuable suggestions, which are listed in the Recommendations section below.

Volumetric Analysis. A volumetric analysis using existing observation ranges was also performed on the water balance through this reach of the Mississippi River. In addition to the USACE-estimated ORCC outflow, the USGS gage for Old River Outflow Channel (USGS gage \# 07381482) was used for comparison. The Vicksburg District also provided a data set of daily Natchez discharges computed from its rating curve. Flows were accumulated into annual volumes of water passing each location using the water year calendar, which extends from October of the previous year to September of the labeled year, as was done in Allison et al. 2012.

Figure 17 shows the comparison of annual water volumes at locations between Natchez and Belle Chasse. Any values not shown are because a significant amount of the year, or the entire year, had missing data. The analysis shows that the mass balance for the river can be closed to within the range of uncertainty associated with each observation, assuming that the range of uncertainty for these observations is on the same order as the standard deviation of the observations at each cross section in the longitudinal study (i.e., 3\%-5\%). The Natchez minus ORCC volume (using either the USACE or USGS estimates of ORCC) tends to be a little larger than the other volumes, except 


\section{MRG\&P}

\section{Mississippi River Geomorphology \& Potamology Program}

for 2011 where the Natchez minus ORCC_USACE volume was lower. Excluding 2008 and 2009, since only some data sets are available, the biggest volume difference occurs between Natchez minus ORCC_USACE and Tarbert Landing in 2013 with a difference of 22,500,000 acre-feet, or $6.1 \%$ of the average of the 2013 volumes. The Tarbert Landing, Baton Rouge, and Belle Chasse data sets agree very well with one another, ranging from within $1.1 \%$ of each other in 2011 up to within $3.2 \%$ in 2015. In many cases, the Tarbert Landing annual volume is smaller than Baton Rouge and/or Belle Chasse, which is evidence against a cumulative downstream loss of water volume, such as groundwater loss.

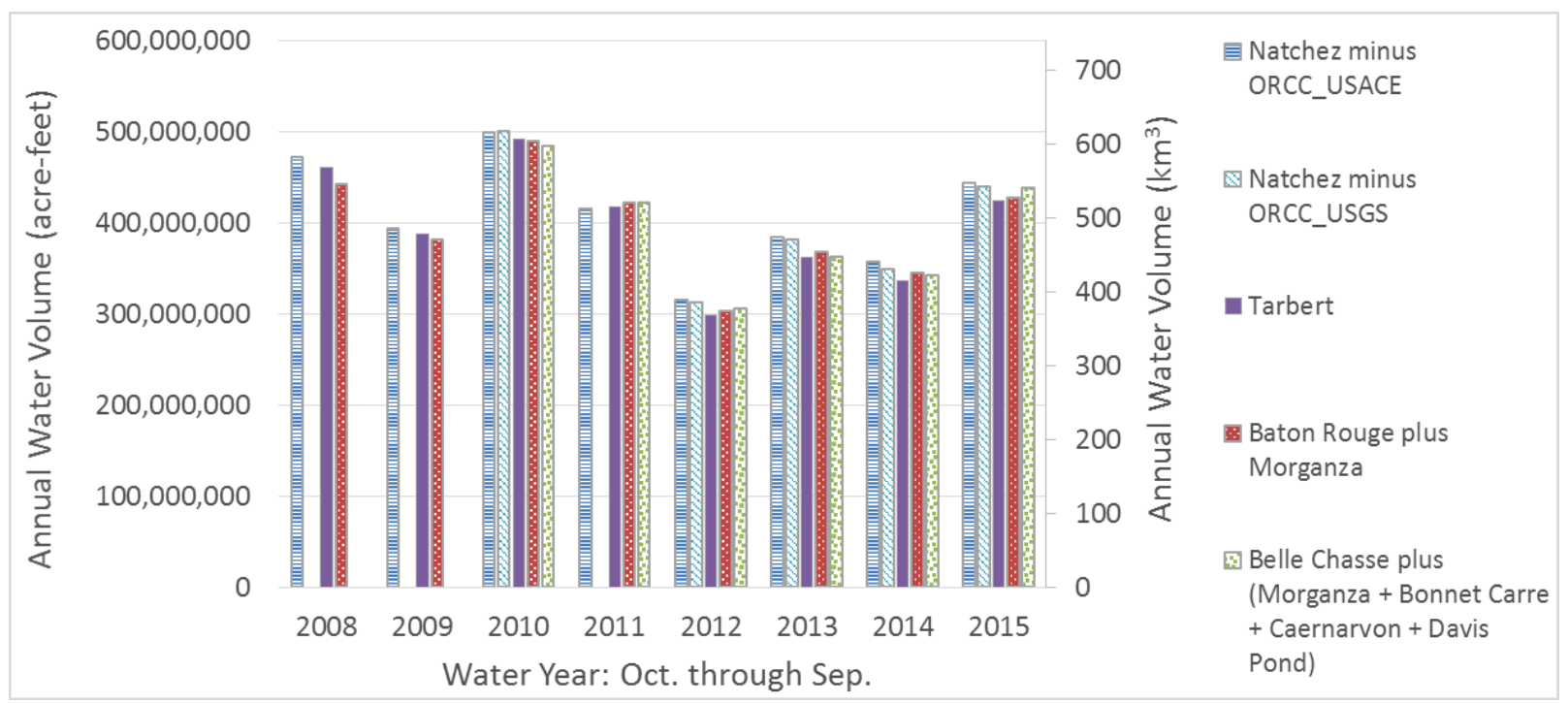

Figure 17. Comparison of annual water volumes.

SUMMARY: Many of the critical water management controls during flood conditions are based on specific flow rate triggers, so understanding flow variability is important. Table 1 shows that no statistically significant trend in water loss can be determined from the discharge observations taken in 2014 and 2015 longitudinally along the Lower Mississippi River during high flow conditions. Discharge measurements between Baton Rouge and Belle Chasse were tidally corrected in order to provide a consistent water budget comparison of the measurements along this reach. Tidal corrections were based on the stage fluctuations at Belle Chasse and interpolated upstream to a zero tidal behavior at Baton Rouge. The time of propagation of the tidal hydraulics was also applied. The Baton Rouge to Belle Chasse reach of the river contained approximately $77 \%-79 \%$ of the discharge recorded upstream at Natchez, MS, for both the 2014 and 2015 measurements. This specific reach of the river did not show a significant amount of water being lost from the river.

These observations, together with the analysis of the existing observation ranges, show that efforts to close the water budget of the Mississippi River to within the expected error at each of the ranges (on the order to $3 \%-5 \%$ ) are not meaningful. Hence, this study has shown that there is no statistically meaningful residual in the water budget, and the association of the residual of this budget with other sources and/or sinks (such as ground water flux) cannot be done. The only way to identify such as residual would be to reduce the observational error at each of the observation ranges. 


\section{MRG\&P \\ Mississippi River Geomorphology \& Potamology Program}

Continued refinement of discharge measurement techniques would be beneficial to narrow the ADCP uncertainty. For large rivers, such as the Mississippi River, even a very small percentage error can represent a large volume of water. For example, a discrepancy of only $5 \%$ is equivalent to $50,000 \mathrm{cfs}$ when the flow in the river is $1,000,000 \mathrm{cfs}$. From Figure 11, the 2014 ADCP measurement at the Baton Rouge location appears to be significantly below the rating curve of the long-term gauging station, but the measurement and rating curve are within $40,000 \mathrm{cfs}$ of each other, which may be within the realm of uncertainty for the 2014 measurements. Going forward, the continued coordination of any state-of-the-art flow measurement technology or standardized procedures is recommended between USACE and others specializing in measuring discharge of large rivers, such as the USGS. The following list of recommendations can be considered for opportunities of improvement.

\section{RECOMMENDATIONS}

- Follow the latest guidelines for ADCP measurement collection, as noted in references such as Mueller et al. (2013), Oberg and Mueller (2007), and Muste et al. (2004a and 2004b). Specific examples from these guidelines that could improve the measurement techniques of this study include the following:

- The use of an external heading reference can reduce the uncertainty of the discharge measurement significantly in comparison to an internal compass.

- For discharge measurements in very deep flow, the measurement frequency may need to be reduced to make sure the entire water depth is being measured appropriately. The Mississippi River contains locations with very large depths, and missing a portion of the bottom of the river can cause a sizeable error in the measurement.

- Discharge measurements should be made in areas where the flow is relatively confined to the banks of the river (i.e., relatively small amount of flow going through the floodplain in order to reduce uncertainty).

- The measurements should follow the timing of the flood peak travel time as best as possible. The longer measurement period in 2016 was likely due to the boat crew being extremely busy at this time.

- Discharge measurements should be made in relatively straight sections of the river in order to reduce uncertainty. Flow should be relatively uniform and free of eddies, slack water, and excessive turbulence (Rantz 1982).

- It is recommended that a potential reduction in uncertainty be given a high priority when considering where to perform discharge measurements. Many discharge measurements are made at specific sites because they have historically been performed in those locations. If a better discharge measurement location is available (i.e., a significant reduction in uncertainty), it is recommended to consider deviating from the historically consistent location. 


\section{MRG\&P \\ Mississippi River Geomorphology \& Potamology Program}

\section{REFERENCES}

Allison, M. A., C. R. Demas, B. A. Ebersole, B. A. Kleiss, C. D. Little, E. A. Meselhe, N. J. Powell, T. C. Pratt, B. M. Vosburg. 2012. A water and sediment budget for the Lower Mississippi-Atchafalaya River in flood years 2008-2010: implications for sediment discharge to the oceans and coastal restoration in Louisiana. Journal of Hydrology 432:84-97.

Biedenharn, D. S., W. A. Stroupe, and J. H. Brooks. 2014. A review of the Lower Mississippi River Potamology Program. MRG\&P Report No. 1. Vicksburg, MS: U.S. Army Corps of Engineers, Mississippi Valley Division. http://acwc.sdp.sirsi.net/client/search/asset/1035268.

Kolker, A. S., J. E. Cable, K. H. Johannesson, M. A. Allison, and L. V. Inniss. 2013. Pathways and processes associated with the transport of groundwater in deltaic systems. Journal of Hydrology 498:319-334.

Mueller, D. S., C. R. Wagner, M. S. Rehmel, K. A. Oberg, and F. Rainville. 2013. Measuring discharge with acoustic Doppler current profilers from a moving boat (ver. 2.0, December 2013). U.S. Geological Survey Techniques and Methods, book 3, chap. A22. http://dx.doi.org/10.3133/tm3A22.

Muste, M., K. Yu, and M. Spasojevic. 2004a. Practical aspects of ADCP data use for quantification of mean river flow characteristics; Part I: moving-vessel measurements. Flow Measurement and Instrumentation 15(1):116.

Muste, M., K. Yu, T. Pratt, and D. Abraham. 2004b. Practical aspects of ADCP data use for quantification of mean river flow characteristics; Part II: fixed-vessel measurements. Flow Measurement and Instrumentation 15(1):17-28.

Oberg, K., and D. S. Mueller. 2007. Validation of streamflow measurements made with acoustic Doppler current profilers. Journal of Hydraulic Engineering 133(12):1421-1432.

O'Brien, P., D. Mueller, and T. Pratt. 2012. Comparison of acoustic doppler current profiler and Price AA mechanical current meter measurements made during the 2011 Mississippi River Flood. In World Environmental and Water Resources Congress 2012: Crossing Boundaries, 1260-1269. doi:10.1061/9780784412312.127.

Rantz, S. E. 1982. Measurement and computation of streamflow: Volume 1, Measurement of stage and discharge (No. 2175). Washington, DC: U.S. Government Printing Office.

Sharp, J., C. Little, G. Brown, T. Pratt, R. Heath, L. Hubbard, F. Pinkard, K. Martin, N. Clifton, D. Perkey, N. Ganesh. 2013. West Bay sediment diversion effects. ERDC/CHL TR-13-15. Vicksburg, MS: U.S. Army Engineer Research and Development Center.

U.S. Army Corps of Engineers (USACE). 2012. Mississippi River and Tributaries System 2011 post-flood report. http://www.mvd.usace.army.mil/Portals/52/docs/regional flood risk management/Docs/MRT PostFloodR eport (Main\%20Report).pdf 